\title{
Bacterial diversity in the sediments of a temperate artificial lake, Rapel reservoir
}

\author{
Diversidad bacteriana en sedimentos de un lago artificial temperado, embalse Rapel
}

\author{
CRISTINA DORADOR ${ }^{1}$, GABRIELA CASTILLO $^{2}, \mathrm{~K}^{\text {P. P. WITZEL }}{ }^{3} \&$ IRMA VILA $^{3}$
}

${ }^{1,3}$ Max Planck Institute for Limnology, PO Box 165, 24306 Plön, Germany e-mail: cdorador@mpil-ploen.mpg.de

${ }^{2}$ Departamento de Ingeniería Civil, Universidad de Chile, PO Box 228-3, Santiago, Chile e-mail: gcastilo@cec.uchile.c1

${ }^{3}$ Departamento de Ciencias Ecológicas, Universidad de Chile, PO Box 653, Santiago, Chile e-mail: limnolog@uchile.cl

\begin{abstract}
Rapel reservoir is an eutrophic system in Chile that has undergone a series of anthropogenic impacts in recent decades. To provide a better understanding of the processes occurring in the reservoir, we examined bacterial composition from surface sediments using traditional microbiology techniques and molecular biology tools. Our results showed significant temporal variation in the physical and chemical composition of the water column, but no depth-related differences during the study period. To detect temporal changes in bacterial composition, cultivable heterotrophic bacteria, heterotrophic iron oxidizing bacteria, and sulfate-reducing bacteria were extracted from the surface sediments and their concentration measured. Microbial diversity in sediments was represented by closest relatives of eight different bacterial phyla. The most frequently recovered phylotypes in the clone library of $16 \mathrm{~S}$ rDNA were related to sulfate-reducing bacteria belong to the Deltaproteobacteria group.
\end{abstract}

Key words: sediments, sulfate-reducing bacteria, 16S rDNA.

\section{RESUMEN}

El embalse Rapel es un sistema eutrófico en Chile que ha experimentado diversos impactos antropogénicos en las últimas décadas. Para conocer mejor los posibles procesos que ocurren en el embalse, la composición bacteriana fue estudiada en la zona superficial de los sedimentos utilizando técnicas microbiológicas tradicionales y herramientas de biología molecular. Nuestros resultados mostraron variación temporal significativa en la composición física y química del agua, no encontrándose diferencias de las variables medidas entre superficie y fondo en la columna de agua durante el período de estudio. Para detectar cambios temporales en la concentración y composición bacteriana, se midieron bacterias heterótrofas, heterótrofas oxidantes de fierro y bacterias reductoras de sulfato extraídas de la superficie de los sedimentos. La diversidad bacteriana en los sedimentos estuvo representada por 8 diferentes Phyla del dominio Bacteria. Los filotipos más frecuentes en la genoteca estuvieron relacionados a bacterias reductoras de sulfato pertenecientes al grupo de Deltaproteobacteria.

Palabras clave: sedimentos, bacterias reductoras de sulfato, ADNr 16S.

\section{INTRODUCTION}

Rapel reservoir is located in Central Chile $\left(34^{\circ}\right.$ $\left.\mathrm{S}, 71^{\circ} \mathrm{W}\right)$ at an altitude of $130 \mathrm{~m}$. This mesotrophic temperate lake was created during 1968 for hydroelectric power generation. The lake has three sub-basins with different physical, chemical and hydrodynamic characteristics (Contreras et al. 1994). The shallowest zone corresponds to Alhué basin
(Fig. 1), which contrasts with the other subbasins as it receives a low discharge $\left(<1 \mathrm{~m}^{3} \mathrm{~s}^{-1}\right)$ but sulfate rich $\left(1,500 \mathrm{mg} \mathrm{L}^{-1}\right)$ inflowing stream that carries mine-water effluents. Rapel reservoir is shallow (mean depth $=6-8 \mathrm{~m}$ ), and wind-effects ensure that the water column is permanently mixed and oxygenated at alkaline pH values (Vila et al. 1997, 2000). Total mixing of the water column during most of the year is similar to many Chilean lakes (Vila et 
al. 2000, Soto 2002). The sediments in this system have a high concentration of reduced chemicals, and gas production is high with $\mathrm{CH}_{4}$ and $\mathrm{N}_{2}$ supersaturation in the surface layers (Adams et al. 2000).

A series of anthropogenic activities have produced significant changes in composition and abundance of phytoplankton communities and in the water quality in the lake (Vila \& Pardo 2003). Several hypotheses could explain the change of the phytoplankton composition in this reservoir. The most accepted are high sulfate levels in the water column (Norici et al. 2005) and possible metal solubilization from the sediments (Vila et al. 2000). As it has been cited for reservoirs with different trophic state, the bacterial activity in the sediments has been linked to the trophic conditions in the water body due to sedimentation of particulate organic matter (Wobus et al. 2003). In Chilean freshwater ecosystems, microbial diversity has been examined as a means of assessing water quality (Miranda \& Castillo 1998). The role of microorganisms in sediment gas production under anoxia or low oxygen conditions is well known. Most work on the microbiology of sediments has been undergone through measurement of decomposition processes and the isolation of microorganisms (Spring et al. 2000). This approach is limited because only between 0.001 to $10 \%$ of the total number of visible cells can be retrieved by isolation (Amann et al. 1995). The introduction of molecular methods based on PCR and sequencing of small-subunit ribosomal RNA genes made it possible to estimate the phylogenetic diversity without culture. A combination of different techniques would allow a better understanding of the complexity of bacterial interactions.

Previous research in Rapel reservoir has focused on limnological aspects (Montecino \& Cabrera 1982, Reynolds et al. 1985, Vila et al. 1987, 1997), and until now, the bacterial diversity in this reservoir has not been examined. To identify and elucidate the possible processes that occur in the interphase sedimentswater of the reservoir, bacterial diversity were determinate in the surface sediments of the Alhué basin by using traditional microbial techniques and molecular approaches, namely analysis of $16 \mathrm{~S}$ rDNA by PCR-DGGE and clone library. At the same time, we measured temporal variation in a series of physico-chemical parameters. We compared the results of clone libraries from the Alhué site which received mine-water discharges with El Manzano, an unimpacted site.

\section{MATERIAL AND METHODS}

\section{Sample analysis}

Water and sediment samples for physical and chemical analyses were obtained monthly between January and June 2002 from two sites (Alhué and El Manzano) at the Alhué basin of Rapel reservoir (Fig. 1). These two stations were selected because Alhué directly receives mining wastes, and El Manzano does not. Water samples were collected with a Van Dorn $3 \mathrm{~L}$ bottle at depths of $0.3,6$ and $8 \mathrm{~m}$ (maximum depth). Temperature was recorded with a digital Hanna HI thermometer, $\mathrm{pH}$ with a Hanna HI $8314 \mathrm{pH}$ meter, and conductivity with a VWR conductivity meter. Dissolved oxygen was measured with the Winkler method, $\mathrm{BOD}_{5}, \mathrm{P}-$ $\mathrm{PO}_{4}{ }^{3-}, \mathrm{N}_{-} \mathrm{NO}_{3}{ }^{-}, \mathrm{S}_{-} \mathrm{SO}_{4}{ }^{2-}$ and chlorophyll $a$ were analyzed according to Standard Methods (APHA 1998). Data were analyzed with two-factor ANOVA and Kendall Tau non parametric correlation ( $\mathrm{P}<0.05)$ (Zar 1996).

Samples were obtained from the upper 15 $\mathrm{cm}$ of the lake sediments using a Phleger core sampler and the sediment was homogenized for subsequent DNA extraction. For DNA analyses, we used sediment samples taken from Alhué (Rap1) and El Manzano sites (Rap2) in July 2003 (Fig. 1).

\section{Bacteria counts}

Aerobic heterotrophic colony-forming units (CFU) per gram dry weight (dw) were determined using prechilled R2A (Difco) plates (Standard Methods, APHA 1998), incubated in the dark at room temperature for 2 weeks. Aerobic heterotrophic iron colony-forming units (CFU) per gram dry weight, were cultivated using a ferric ammonium citrate medium containing in $1 \mathrm{~L}:\left(\mathrm{NH}_{4}\right)_{2} \mathrm{SO}_{4}, 0.5 \mathrm{~g}$; $\mathrm{NaNO}_{3}, 0.5 \mathrm{~g} ; \mathrm{K}_{2} \mathrm{HPO}_{4}, 0.5 \mathrm{~g} ; \mathrm{MgSO}_{4} \cdot 7 \mathrm{H}_{2} \mathrm{O}$, $0.5 \mathrm{~g}$; $\mathrm{Ca} \mathrm{Cl} 2.6 \mathrm{H}_{2} \mathrm{O}, 0.2 \mathrm{~g}$; ferric ammonium citrate, $10.0 \mathrm{~g}$, and agar, $15 \mathrm{~g}$, at $\mathrm{pH}$ 6.7. After 10 days of incubation at $20{ }^{\circ} \mathrm{C}$, count colonies 
that show ferric or coffee colour (CETESB, 1992). Five-tube most probable number (MPN) estimations for sulfate-reducing bacteria (SRB) were performed in test tubes containing liquid medium with the following composition in $1 \mathrm{~L}$ water: sodium lactate, $3.5 \mathrm{~g} ; \mathrm{NH}_{4} \mathrm{Cl}, 1 \mathrm{~g}$; $\mathrm{K}_{2} \mathrm{HPO}_{4}, 0.5 \mathrm{~g} ; \mathrm{MgSO}_{4} 7 \mathrm{H}_{2} \mathrm{O}, 2 \mathrm{~g} ; \mathrm{Na}_{2} \mathrm{SO}_{4}, 0,5$ $\mathrm{g} ; \mathrm{CaCl}_{2} .2 \mathrm{H}_{2} \mathrm{O}, 0.1 \mathrm{~g} ;\left(\mathrm{NH}_{4}\right)_{2} \mathrm{SO}_{4} \cdot \mathrm{FeSO}_{4} \cdot 6 \mathrm{H}_{2} \mathrm{O}$; yeast extract, $1 \mathrm{~g}$, at $\mathrm{pH}$ 7.2. Inoculated tubes were incubated at dark in anaerobic conditions at $20{ }^{\circ} \mathrm{C}$ for 21 days. The growth was detected by $\mathrm{H}_{2} \mathrm{~S}$ production and black precipitation
(CETESB, 1992). Results were expressed as Most Probable Number of SRB (Desulfovibrio) per 100 gram dry weight, according to standard probability tables.

\section{Metals}

Total iron and copper in the sediments were analyzed by atomic absorption spectroscopy. A sediments microscopic mineralogical composition analysis was conducted following Siegel (1999).

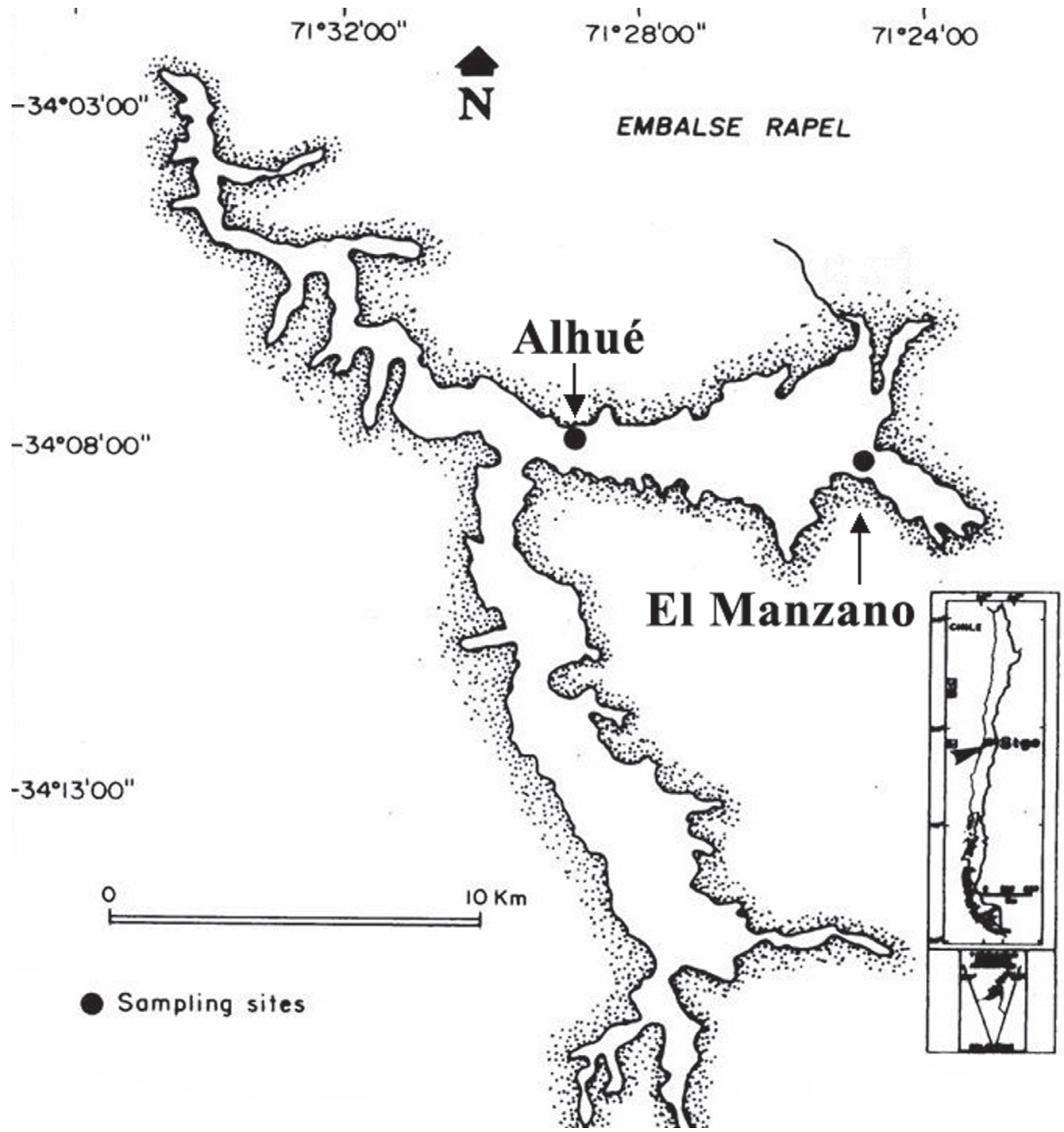

Fig. 1: Geographic location of Rapel reservoir, Alhué and El Manzano sites Ubicación geográfica de los sitios Alhué y El Manzano en el embalse Rapel. 


\section{DNA extraction}

Aliquots of $0.25 \mathrm{~g}$ of sediments were used for DNA extraction using Ultra Clean Soil DNA Isolation Kits (MoBio Lab., Inc., Solana Beach, California, USA). DNA was dissolved in 10 mM Tris- $\mathrm{HCl}$ buffer and stored at $-18{ }^{\circ} \mathrm{C}$. DNA quality was checked by $0.8 \%$ agarose gel electrophoresis and staining with ethidium bromide.

\section{PCR amplification}

Oligonucleotide primers Eub9-27F and Eub1542R were used to amplify eubacterial 16S rDNA (Brosius et al. 1981). Each PCR reaction contained 10X PCR-buffer with $2 \mathrm{mM}$ $\mathrm{MgCl}_{2}$ (Roche), $200 \mathrm{mM}$ dNTP mixture (Gibco), 1 pmol of each primer, $2.5 \mathrm{U}$ Taq DNA polymerase (Roche), 10-100 ng template DNA and sterile HPLC grade water to a final volumen of $50 \mu \mathrm{l}$. The PCR was performed using the following conditions: initial denaturing step of $5 \mathrm{~min}$ at $94{ }^{\circ} \mathrm{C}$ followed by 34 cycles of denaturing at $94{ }^{\circ} \mathrm{C}$ for $30 \mathrm{sec}$, annealing at $40{ }^{\circ} \mathrm{C}$ for $45 \mathrm{sec}$ and elongation at $72{ }^{\circ} \mathrm{C}$ for $1.5 \mathrm{~min}$. An annealing temperature at $40{ }^{\circ} \mathrm{C}$ was used in order to maximise the number and diversity of bacteria recovered.

\section{$D G G E$ analysis}

DGGE was performed according to Muyzer et al (1993). The fragments were amplified with the primer combination $\mathrm{P} 2-\mathrm{P} 3$. PCR products were applied onto $7.5 \%$ polyacrylamide gels containing a linear gradient of 30-60\% denaturant where $100 \%$ denaturant was defined as $7 \mathrm{M}$ urea and $40 \%$ deionized formamide. Electrophoresis was carried out in a BioRad D Gene System (BioRad, Munich, Germany) at $60{ }^{\circ} \mathrm{C}, 200 \mathrm{~V}$ for $6 \mathrm{~h}$. The gels were stained with silver nitrate.

\section{Cloning and 16S rRNA gene sequence analysis}

Purified amplicons prepared with proof reading DNA polymerase $(p f u)$ were cloned into Escherichia coli using the pCR-Blunt vector (Invitrogen, San Diego, California, USA) according to the manufacturer instructions. Clones with correct rDNA insertion were initially identified using whole-cell PCR with vector-specific $\mathrm{M} 13 \mathrm{~F} / \mathrm{R}$ primers and checked for appropriate length by agarose gel electrophoresis. For sequencing, the PCR products of correct size were purified in multiscreen cleanup plates (Millipore) and quantified after agarose electrophoresis and ethidium bromide staining via the Molecular Analyst package (BioRad). To screen clones, cycle sequencing was performed with primer 341F (Muyzer et al 1993) using the BigDye Terminator Cycle Sequencing Kit v3.1 and analyzed on an automatic capillary sequencer (model 3100 Gene Analyzer, Applied Biosystems).

\section{Phylogenetic analysis}

The 16S rDNA sequences were analyzed in BLAST search (http://www.ncbi.nlm.nih.gov/ blast) in order to determine the closest relatives in the database. Sequences were aligned using CLUSTALX v1.81 (Thompson et al. 1997). Phylogenetic relationships of the sequences were calculated using distance matrix methods (Neighbor-joining) in MEGA 3.1 (Kumar et al. 2004), with 1000 bootstrap permutations. The reference strains and sequences were obtained via BLAST searches in GenBank. Sequences with similarities $\geq 99 \%$ were considered to represent the same phylotype. Rarefaction curves (Simberloff 1972) were determined by RARFAC program (http://www.icbm.de/pmbio/ downlist.htm).

\section{Nucleotide sequence accession numbers}

The nucleotide sequences of bacterial 16S rDNA sequences have been deposited in GenBank with accession numbers: EF192877-EF192915.

\section{RESULTS}

\section{Water column characteristics}

Table 1 details the physic and chemical characteristics of Alhué basin water column. No significant differences were found between samples collected from surface and deeper waters (two-way ANOVA without replication). Therefore, the results shown in Table 1 are mean values, with standard deviations from three depths. Temporal variations show the typical 
decrease of water temperature between summer and winter. Only $\mathrm{N}-\mathrm{NO}_{3}{ }^{-}$concentrations showed significant differences among the sampling periods $\left(\mathrm{F}_{1},=168.07, \mathrm{P}<0.0001\right)$, and there were no significant temporal variation in any of the other chemical variables (two-way ANOVA without replication). Both $\mathrm{pH}$ and conductivity increased with time. Oxygen saturation was below $100 \%$ during January, March and June at all depths (Table 1). The change in chemical characteristics in the water column during June coincided with heavy rain and inflow versus outflow and manipulation of lake levels.

The concentration ranges of the nutrients $\mathrm{N}$ $\mathrm{NO}_{3}{ }^{-}, \mathrm{P}-\mathrm{PO}_{4}{ }^{3-}$ and chlorophyll $a$ corresponded to a meso-eutrophic lake (Ryding \& Rast 1992) (Table 1). There was no difference between ammonium values recorded in surface and deeper waters. Sulfate values were homogenous in the water column.

\section{Sediments characteristics}

The following metallic mineral items were identified at the trace level in sediment samples: Magnetite $\left(\mathrm{FeOFe}_{2} \mathrm{O}_{3}\right)$; Hematite $\left(\mathrm{Fe}_{2} \mathrm{O}_{3}\right)$; Pyrite melnikovitika $\left(\mathrm{FeS}_{2}\right)$ and Chalcopyrite $\left(\mathrm{CuFeS}_{2}\right)$. Several non-metallic mineral species were also found (Orthoclase, Hydromuscovite,
Chlorite, Mica of Biotites, Quartz, Glass, Epidote, Zircon and, Rutile). Chemical analysis of sediments showed the following values: 24.3 $\mathrm{mg} \mathrm{g}^{-1}$ dry weight of total $\mathrm{Fe}$ and $1.2 \mathrm{mg} \mathrm{mL}^{-1}$ dissolved Fe; $0.34 \mathrm{mg} \mathrm{g}^{-1}$ dry weight of total $\mathrm{Cu}$ and $<0.1 \mathrm{mg} \mathrm{mL}^{-1}$ dissolved $\mathrm{Cu}$.

\section{Bacteria of the sediment water interphase}

Fig. 2 shows the heterotrophic, iron oxidizing and sulfate-reducing bacteria concentration found during the study period. The level of heterotrophic bacteria is similar compared with other meso-eutrophic systems (Wobus et al. 2003 ) and with low seasonal variation (6.9x 106-9.7 $\times 10^{6}$ CFU g dry weight ${ }^{-1}$ ).

Generally, heterotrophic iron oxidizing bacteria were more abundant during autumn, and showed a general decrease between January and April, but subsequently increased by three orders of magnitude in May $\left(3.1 \times 10^{3}-3.7 \times 10^{6} \mathrm{CFU} g\right.$ $\left.\mathrm{dw}^{-1}\right)$. It is important to note the presence of sulfate-reducing bacteria in the upper sections of the sediment. MPN values that fluctuated between $10^{2}$ and $10^{4} \mathrm{MPN} \mathrm{g} \mathrm{dw}^{-1}$, and showed a positive significant correlation between sulfate content in the water column and sulfate reducing bacteria found in sediments (Kendall Tau, $\mathrm{n}=5$, $\mathrm{Z}=2.45, \mathrm{P}<0.01)$.

TABLE 1

Variation in mean $( \pm 1 \mathrm{SD})$ physico-chemical and biological parameters recorded from the water column of Alhué basin, Rapel reservoir, (January-June, 2002)

Valores químicos, físicos y biológicos promedios $( \pm 1 \mathrm{DE})$ de la columna de agua en la cubeta Alhué del embalse Rapel

\begin{tabular}{lccccc}
\hline Mean value & January & March & April & May & June \\
\hline Temperature $\left({ }^{\circ} \mathrm{C}\right)$ & $24.4 \pm 0,0$ & $24.1 \pm 0.1$ & $20.8 \pm 0.1$ & $14.1 \pm 0.0$ & $11.0 \pm 0.1$ \\
Dissolved oxygen $\left(\mathrm{mg} \mathrm{L}^{-1}\right)$ & $7.8 \pm 0.1$ & $7.8 \pm 0.3$ & $8.7 \pm 0.6$ & $11.6 \pm 0.5$ & $8.5 \pm 0.0$ \\
Saturation \% & $95.5 \pm 0.6$ & $94.7 \pm 3.6$ & $101.0 \pm 7.4$ & $117.5 \pm 5.5$ & $80.3 \pm 0.3$ \\
$\mathrm{BOD}_{5}\left(\mathrm{mg} \mathrm{L}^{-1}\right)$ & 3.7 & n. d & 2.7 & 0.7 & $\mathrm{n} . \mathrm{d}$ \\
$\mathrm{Conductivity}$ & $477.0 \pm 0.0$ & $474.0 \pm 0.0$ & $488.0 \pm 0.0$ & $531.0 \pm 0.0$ & $349.0 \pm 0.0$ \\
$\mathrm{pH}$ & $7.8 \pm 0.0$ & $8.8 \pm 0.1$ & $8.8 \pm 0.1$ & $9.0 \pm 0.0$ & $7.7 \pm 0.1$ \\
$\mathrm{P}-\mathrm{PO}_{4}\left(\mu \mathrm{g} \mathrm{L}^{-1}\right)$ & $34.1 \pm 4.9$ & $35.4 \pm 2.8$ & $42.4 \pm 5.7$ & $92.4 \pm 72.1$ & $190.5 \pm 3.5$ \\
$\mathrm{~N}-\mathrm{NO}_{3}\left(\mu \mathrm{g} \mathrm{L}^{-1}\right)$ & $197.0 \pm 165.0$ & $698.2 \pm 119.0$ & $338.2 \pm 50.7$ & $904.0 \pm 150.8$ & $1019.0 \pm 268.7$ \\
$\mathrm{~N}_{-} \mathrm{NH}_{4}\left(\mu \mathrm{g} \mathrm{L}^{-1}\right)$ & $82.2 \pm 36.8$ & $74.8 \pm 33.9$ & $114.3 \pm 5.0$ & $51.9 \pm 6.2$ & $184.2 \pm 17.7$ \\
$\mathrm{HCO}_{3}\left(\mathrm{mg} \mathrm{L}^{-1}\right)$ & $389.0 \pm 8.5$ & $210.0 \pm 3.5$ & $212.0 \pm 11.3$ & $230.0 \pm 14.1$ & $160.0 \pm 14.1$ \\
$\mathrm{Alkalinity}(\mathrm{mM})_{\mathrm{SO}_{4}{ }^{2-}\left(\mathrm{mg} \mathrm{L}^{-1}\right)}$ & $0.7 \pm 0$ & $0.7 \pm 0.1$ & $0.7 \pm 0.08$ & $0.65 \pm 0.07$ & $0.57 \pm 0.03$ \\
$\left.\mathrm{Chl} \mathrm{a}^{-1} \mu \mathrm{g} \mathrm{L}^{-1}\right)$ & $117.7 \pm 0.9$ & $53.4 \pm 2.8$ & $46.4 \pm 0.5$ & $52.5 \pm 1.1$ & $30.0 \pm 0.8$ \\
\hline
\end{tabular}

nd: Mot determinated 


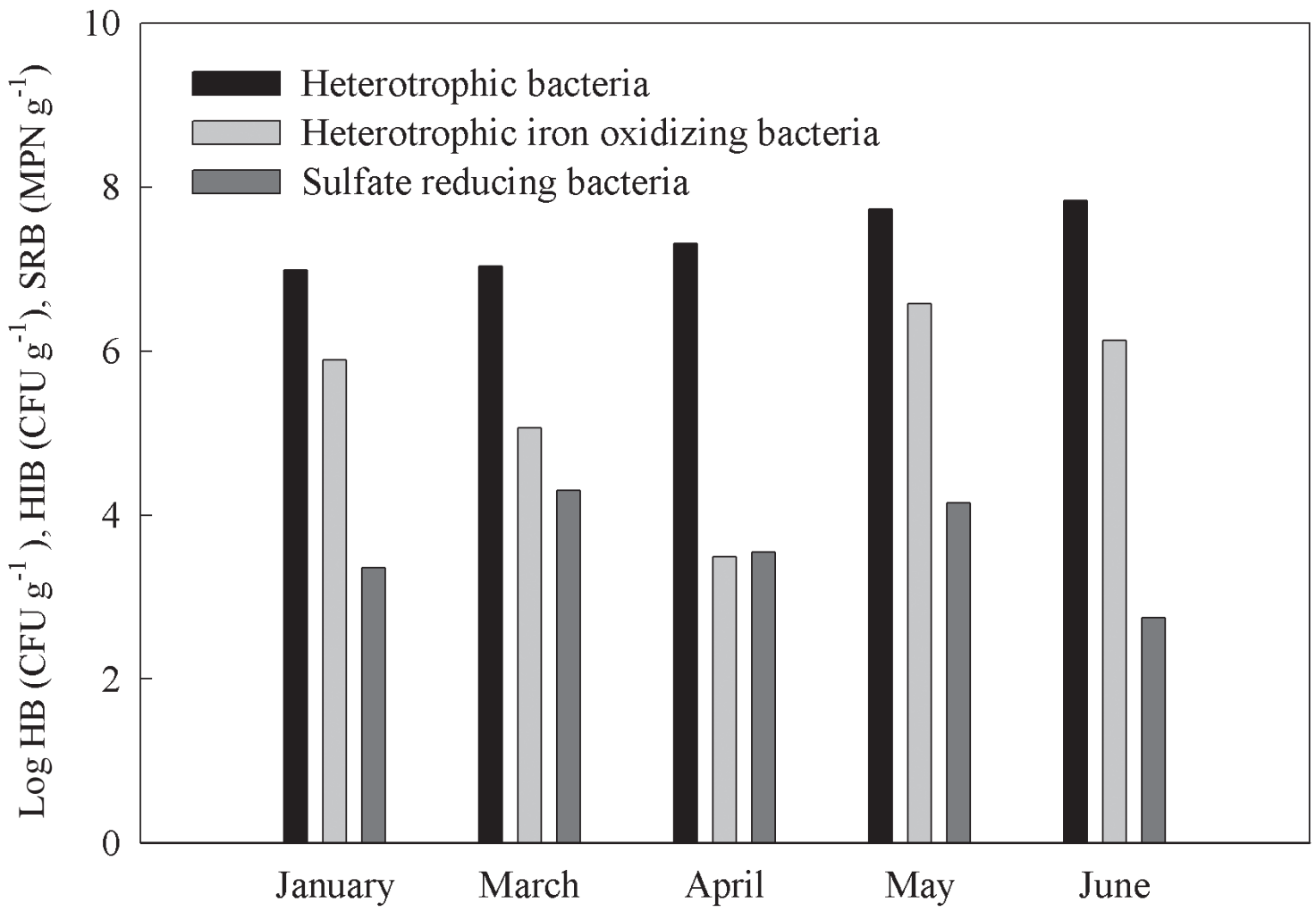

Fig. 2: Bacterial numbers in the upper $15 \mathrm{~cm}$ of sediment from Rapel reservoir, Alhué basin. $\mathrm{HB}=$ Heterotrophic bacteria, HIB = heterotrophic iron oxidizing bacteria, SRB = sulphate reducing bacteria. Note log scale on vertical axis.

Número de bacterias en los primeros $15 \mathrm{~cm}$ de sedimento del embalse Rapel, cubeta Alhué. HB = Bacterias heterótrofas, $\mathrm{HIB}=$ bacterias heterótrofas oxidantes de fierro, $\mathrm{SRB}=$ bacterias reductoras de sulfato.

\section{$D G G E$}

We used the frequency of DGGE bands as an estimate of microbial richness. Richness was higher in El Manzano site (20) than in Alhué (16) and the bacterial composition was quite similar (Fig 3). For the identification of the bands in the environmental samples we used eight selected clones from the two clone libraries (Liu et al. 2002) (Table 3). The sequences shared similarity values ranging between $87 \%$ and $95 \%$ with cultured species, the higher values corresponding to those taxa most closely related to Deltaproteobacteria.

\section{Clone library and bacterial diversity}

Ninety-six clones per sample were arbitrarily selected for analysis and fifty-five sequences with the correct insert were recovered. Thirtyfive sequences were used for phylogenetic tree construction. Each sequence was used as representative clones and reference organisms were selected as the closest relatives to samples sequences from the database. Rarefaction curves were used to determine if a sufficient number of clones were screened to estimate total diversity in each clone library. A combined rarefaction curve for both Alhué and El Manzano sites reached an asymptotic maximum (Fig. 4). We found clones related to eight different phylogenetic groups. The majority of sequences $(67 \%)$ were grouped to the Proteobacteria phylum dominated by the Deltaproteobacterium group (24\%), (Table 2), which in this case corresponds to sulfatereducing bacteria. Other Proteobacteria represented in the clone library were Alphaproteobacteria (12\%), Gammaproteobacteria (19\%) and Betaproteobacteria (11\%). Further, Cytophaga-Flavobacteria-Bacteroidetes (CFB) (12\%), Firmicutes (5\%) 


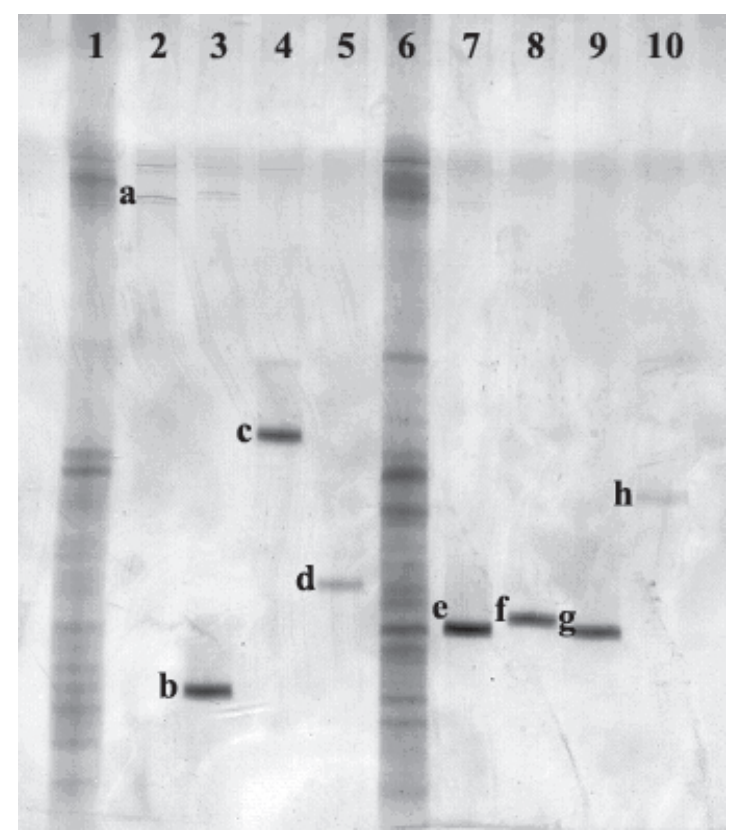

Fig. 3: DGGE pattern of two sites in Rapel Alhué basin reservoir. Line 1: Alhué site sediment (Rap1), line 2: clone Rap1_23D, line 3: clone Rap1_22D, line 4: clone Rap1_6A, line 5: clone Rap1_43D, line 6: El Manzano site sediment (Rap2), line 7: clone Rap2_3A, line 8: clone Rap2_2B, line 9: clone Rap2_15C, line 10: clone Rap2_1D.

Patrón de bandas de DGGE en embalse Rapel. Carril 1: Sedimento cubeta Alhué (Rap1), carril 2: clon Rap2_23D, carril 3: clon Rap1_22D, carril 4: clon Rap1_6A, carril 5: clon Rap1_43D, carril 6: Sedimento sitio El Manzano (Rap2), carril 7: clon Rap2_3A, carril 8: clon Rap2_2B, carril 9: clon Rap2_15C, carril 10: clon Rap2_1D.

Verrumicrobia (4\%) were present in the clone library (Fig. 5). Twelfth percent of the sequences did not have a clear classification inside the phylum Bacteria. Only $27 \%$ percent of sequences shared more than $97 \%$ sequence identity with the first entry in the BLAST search, the rest of the sequences had more than $90 \%$ similarity. Sixty-two percent of the sequences were classified in the BLAST search as uncultured bacteria, which means that most of the sequences does not have similarity with already cultured bacteria.

\section{DISCUSSION}

The significant physic and chemical seasonal differences reported here were similar to those previously reported for Rapel reservoir (Vila et al. 2000). The concentrations of heterotrophic bacteria we describe correspond to those previously described in the literature for reservoirs in the process of eutrophication (Wobus et al. 2003). This is indicative of important biological activity at the sediments of the Alhué basin; a gradual increase in bacterial abundance was observed between January and June and, this coincides with higher chlorophyll $a$ values during the same period. The presence of iron oxidizing bacteria in our samples may be indicative of the presence of $\mathrm{Fe}$ (II) associated with organic matter, and which could be oxidized to Fe (III). In spite of the low availability of degradable organic matter found (deduced from $\mathrm{BOD}_{5}$ ), we have shown that there are high concentrations of iron in the sediments compared to other metals like $\mathrm{Mn}, \mathrm{Cu}$ and $\mathrm{Zn}$. According to metals analysis, iron is associated to metals and other elements (Pizarro et al. 2003). Higher values of iron oxidizing bacteria during May and June coincided with the reservoir volume increase and with the opening of the floodgates, due to heavy rain, which would imply particulate material incorporation and consequently an increase in the availability of organic matter.

Recently, it has been demonstrated that sulfate-reducing bacteria are present in oxygenated and anoxygenic environments, especially those close to surface sediments (Cypionka 2000, Dolla et al. 2006). This might explain the results of this study, e.g. the presence of SRB in sediments and water column. Cypionka (2000) noted that it is possible to detect two equivalent peaks of SRB at different depths, one in anoxic zones and the other at the water sediment interphase. DGGE analyses demonstrated a greater number of bands at the El Manzano site, but few qualitative differences with the Alhué sites. The clone library confirmed this result, as the number of phylotypes was higher in El Manzano site than at Alhué. In total, eight different Phyla of the Bacteria domain were found, with the sulfate-reducing bacteria group the most abundant. This group has an important role in heavy metal precipitation in sediments, which is dependent on $\mathrm{pH}$ and redox potential. They participate in other biogeochemical cycles including phosphite oxidation (Schink \& Friederich 2000, Schink et al. 2002), reduction 
of $\mathrm{Fe}(\mathrm{III})$ (Coleman et al. 1993) and the precipitation of arsenic (Rittle et al. 1995, Kirk et al. 2004). Mining activities in the catchment area of Rapel reservoir have increased the amounts of sulfate and heavy metals entering the lake due to inflow of clear water tailings (Vila et al. 2000). Kirk et al. (2004) emphasize the role of sulfate-reducing bacteria in freshwater systems because in the absence of sulfate reduction, methanogenesis is the dominant type of microbial metabolism, and arsenic accumulates to high levels. In Rapel reservoir the flux of $\mathrm{CH}_{4}$ from the sediments is high (Adams et al. 2000) but oxygen in the water column prevents bubble formation, and $\mathrm{CO}_{2}$ is produced. Currently, nothing is known regarding the flux or production rates of $\mathrm{H}_{2} \mathrm{~S}$ in the Rapel Reservoir. It may be that sulfate reduction might limit heavy metal solubilization, which would explain the low amounts of $\mathrm{Cu}, \mathrm{Zn}$ and other metals in the water column (Vila et al. 2000) in spite of the constant inflow of mine tailings.
Desulfotignum phosphitoxidans, a sulfate reducing bacterium isolated from marine sediments that utilises phosphite as its sole electron donor and $\mathrm{CO}_{2}$ its only carbon source (Schink et al. 2002), was the closest relative for most of the clones in the library. Some clones were related to Geobacter and Desulfobacterium. It has been described that this kind of bacteria are able to reduce Fe (III) under anaerobic conditions. This process is one of the most important geochemical changes in aquatic sediments (Lovley 2004). Some sequences related to the group of methanotrophic bacteria (Methylocaldum, Methylophilus) might play an important role in the methane oxidation, due to the high methane production in the Rapel Reservoir (as described by Adams et al. 2000). It is important to determine the role and dynamics of both processes (methanogenesis, sulfate reduction) because these would be responsible for rapid chemical changes in the lake, which are likely to have detrimental consequences for the biota (Vila et al. 2000).

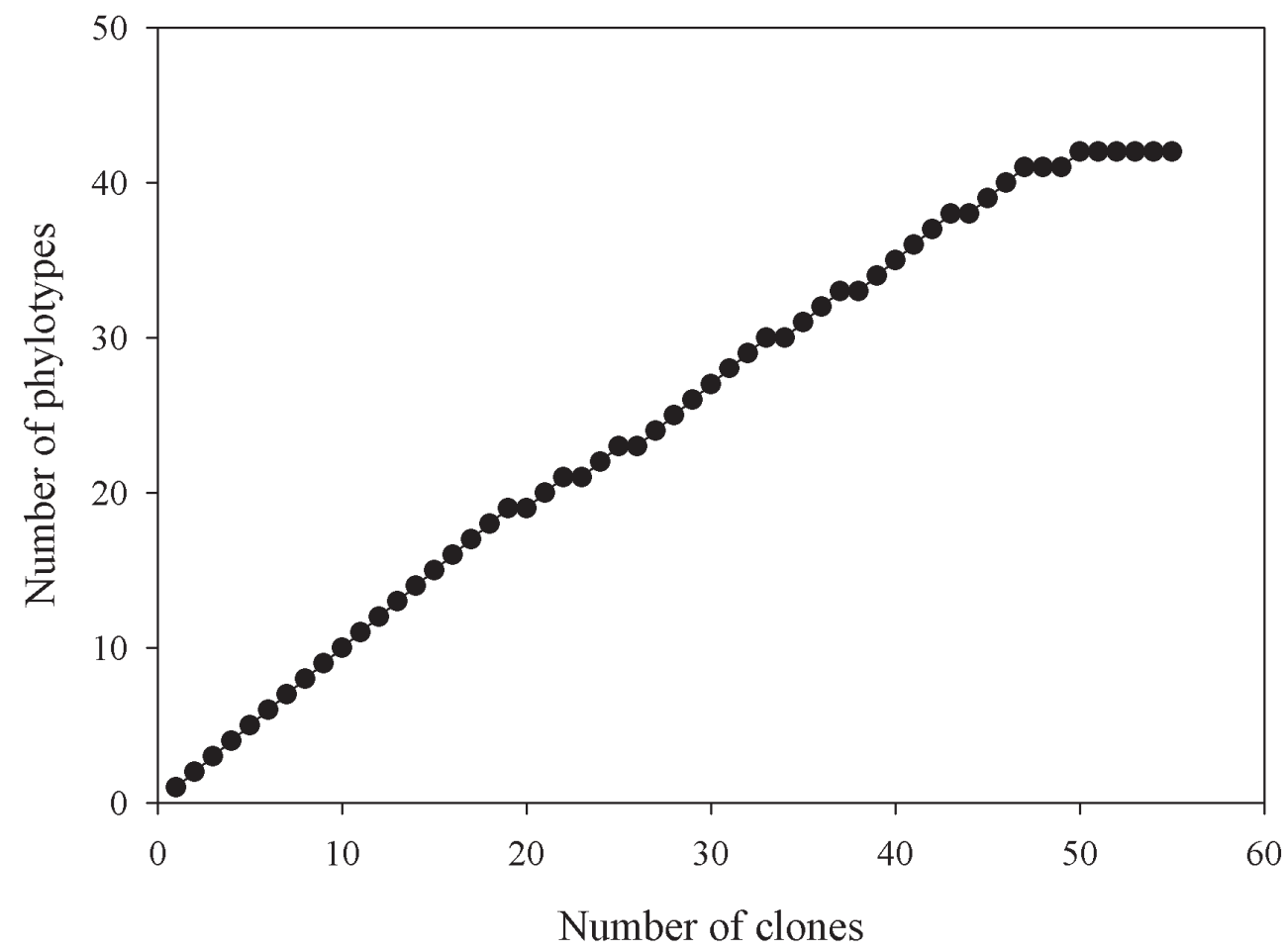

Fig. 4: Rarefaction analysis of clone libraries from Alhué and El Manzano sites in Rapel reservoir, showing asymptote at $n=42$.

Análisis de rarefacción de genotecas de Alhué y El Manzano en Embalse Rapel, la asíntota se encuentra a n = 42 . 


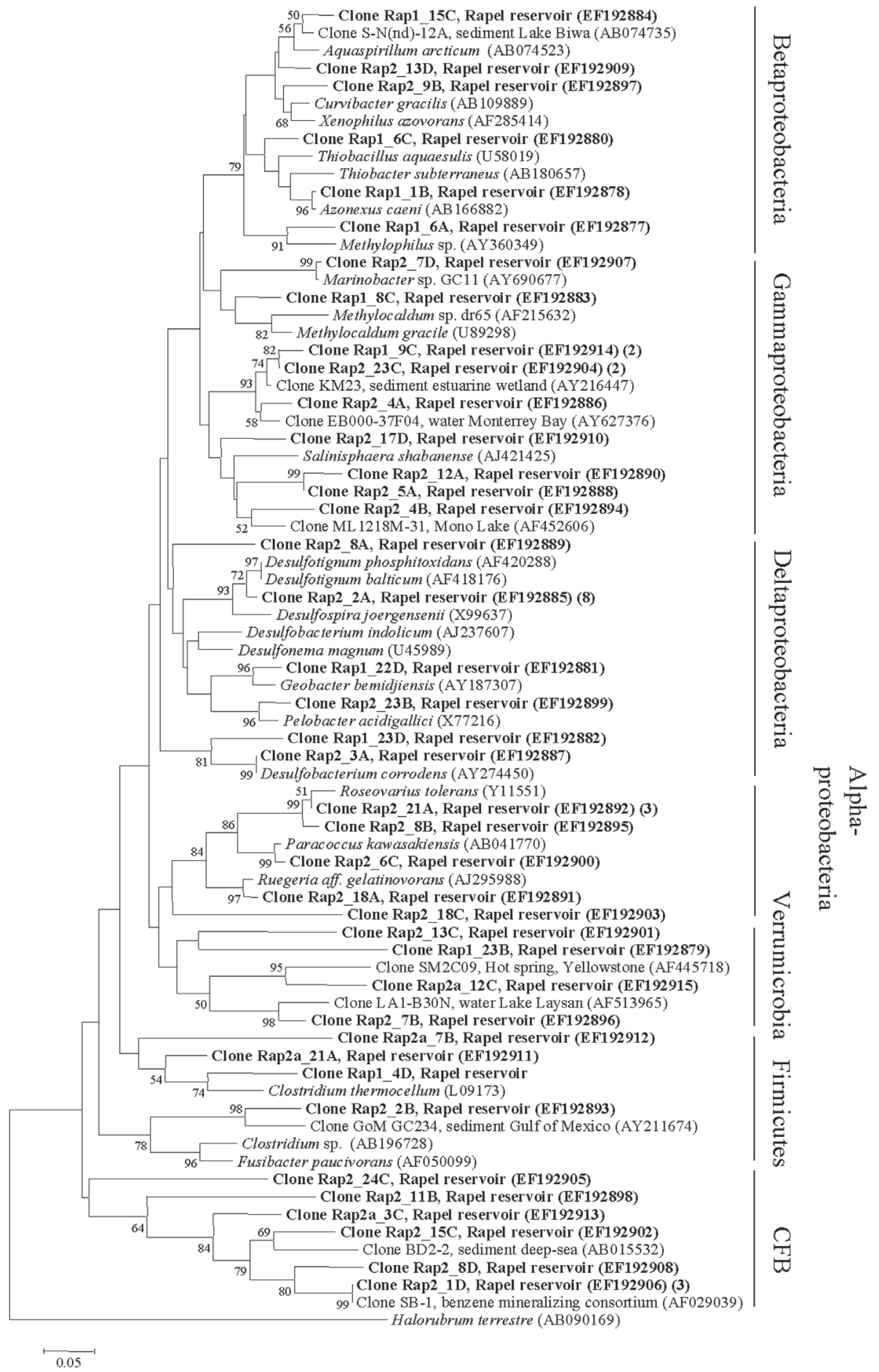

Fig. 5: Phylogenetic tree from 16S rDNA sequences determined by distance Jukes-Cantor analysis from sediments of two sites of Rapel reservoir. GenBank accession numbers are in parentheses. Number in brackets $(*)$ represents the number of clones with similar sequence. Boostrap percentages greater than $50 \%$ were reported. Scale bar represents substitution per nucleotide position.

Árbol filogenético de las secuencias del ADNr 16S obtenidas desde los sedimentos de dos sitios en el embalse Rapel, determinadas por el análisis de distancia de Jukes-Cantor. Los números entre paréntesis (*) representan el número de clones con secuencia similar. Se muestran los porcentajes de "boostrap" mayores del $50 \%$. La escala representa el número de sustituciones por nucleótido. 
TABLE 2

Taxonomy of $16 \mathrm{~S}$ rDNA clone library sequences

Taxonomía de las secuencias de $16 \mathrm{~S}$ rDNA en la genoteca

\begin{tabular}{lccc}
\hline Phylogenetic group & Bacterial sequences in clone libraries (\%) & \multicolumn{2}{c}{ Number of sequences in sampling station } \\
\cline { 3 - 4 } & & Alhué & El Manzano \\
\hline Acidobacteria & 4 & 1 & 2 \\
Actinobacteria & 5 & 0 & 2 \\
Firmicutes & 7 & 4 & 4 \\
Deltaproteobacteria & 25 & 2 & 5 \\
Gammaproteobacteria & 16 & 5 & 7 \\
Betaproteobacteria & 13 & 1 & 8 \\
Alphaproteobacteria & 15 & 2 & 4 \\
CFB & 15 & & \\
\hline
\end{tabular}

TABLA 3

Representative clones bands in DGGE

Bandas de clones representativos en DGGE

\begin{tabular}{lcllc}
\hline Clone name & Band & Closest relative & Phylogenetic group & Similarity (\%) \\
\hline Rap1_23D & a & Desulfobacterium cathecolicum (AJ237602) & Deltaproteobacteria & 95 \\
Rap1_22D & b & Geobacter bemidjiensis (AY187307) & Deltaproteobacteria & 95 \\
Rap1_6 & c & Methylophilus sp. 040703/8067S (AY360349) & Betaproteobacteria & 94 \\
Rap1_4D & d & Clostridium thermocellum (L09173) & Firmicutes & 92 \\
Rap2_3 & e & Desulfobacterium corrodens (AY274450) & Deltaproteobacteria & 96 \\
Rap2_2B & f & Clostridium sp. BA-1 (AB196728) & Firmicutes & 87 \\
Rap2_15C & g & Cytophaga sp. strain BD2-2 (AB015532) & CF-Bacteroidetes & 92 \\
Rap2_1D & h & Cytophaga sp. strain BD1-16 (AB015525) & CF-Bacteroidetes & 91 \\
\hline
\end{tabular}

The other groups found were Alphaproteobacteria, Betaproteobacteria and Gammaproteobacteria, Cytophaga Flavobacteria Bacteroidetes group (CFB), Firmicutes and Verrumicrobia. The Alphaproteobacteria are related with the widespread Roseobacter group, being the most abundant bacterial group in many aquatic systems (Kirchman 2002).

The fact that elevated concentrations of sulfate have entered the lake for several decades might explain the bacterial diversity we report here. For example, there is sufficient available substrate for the development of sulfate-depending organisms, which is confirmed by the high SRB-MPN. A study in four reservoirs of different trophic state
(Wobus et al. 2003) showed that under mesotrophic conditions, the clone library was dominated by CFB but in a highly eutrophic reservoir the more abundant sequences correponded to Firmicutes, Cyanobacteria and Alphaproteobacteria. In comparison with Rapel reservoir, only $4 \%$ of the sequences belong to Fimicutes, and Cyanobacteria have not been recorded for at least a decade (Vila et al. 2000), an unexpected situation, when one considers the trophic state of the lake (Van der Gucht et al. 2005). We emphasize the presence of SRB members considering the totally oxygenated water column but we need more chemical and physical studies in the sediment to understand the bacterial processes and the role of the sulfates in the sediments. 


\section{ACKNOWLEDGMENTS}

The authors thank Patricio Acuña, Rodrigo Pardo and Andrés Ramos for their help in sampling, Margarita Carú for support in molecular analysis, Vilma Barrera and Viviana Lorca for chemical and bacteriological analysis, Pilar Corredor for her comments and Chris Harrod for his valuable comments and english correction. Two anonymous reviewers improved the paper with their critics.

\section{LITERATURE CITED}

ADAMS DD, I VILA, J PIZARRO \& C SALAZAR (2000) Gases in the sediments of two eutrophic Chilean reservoirs: potential sediment oxygen demand and sediment-water flux of $\mathrm{CH}_{4}$ and $\mathrm{CO}_{2}$ before and after an El Niño event. Verhandlungen der Internationalen Vereiningung für theoretische und angewandte Limnologie 27: 1376-1381.

AMANN RI, W LUDWIG \& KH SCHLEIFER (1995) Phylogenetic identification and in situ detection of individual microbial cells without cultivation. Microbiology and Molecular Biology Reviews 59: 143-169.

AMERICAN PUBLIC HEALTH ASSOCIATION (1998) Standard Methods for the examination of water and wastewater. Twentieth edition. Baltimore, Maryland, USA. 1,325 pp.

BROSIUS J, TJ DULL, DD SLEETER \& HF NOLLER (1981) Gene organization and primary structure of a ribosomal RNA operon from Escherichia coli. Journal of Molecular Biology 148: 107-127.

COMPANHIA DE TECNOLOGIA DE SANEAMENTO AMBIENTAL (1992) Análisis microbiológicas de aguas. Contagens de colonias de bactérias que precipitam o ferro:1-10; Determinaçao do Número Mais Provável (N. M. P.) de bactérias redutoras do sulfato (Desulfovibrio) pela técnica de tubos múltiplos. L5.210. 1-11. CETESB. Sao Paulo, Brasil.

COLEMAN ML; DB HEDRICK; DD LOVLEY; DC WHITE \& K PYE (1993) Reduction of Fe(III) in sediments by sulphate-reducing bacteria. Nature 361: 436-438

CONTRERAS M, H VILLAGRÁN \& C SALAZAR (1994) Características hidrodinámicas del Embalse Rapel Medio Ambiente (Chile) 12: 767-773.

CYPIONKA H (2000) Oxygen respiration by Desulfovibrio species. Annual Review of Microbiology 54: 827-848.

DOLLA A, FOURNIER $M$ \& Z DERMOUN (in press) Oxygen defense in sulfate-reducing bacteria. Journal of Biotechnology.

KIRK MF, HOLM TR, PARK J, JIN Q, SANFORD RA, FOUKE BW \& CM BETHKE (2004) Bacterial sulfate reduction limits natural arsenic contamination in groundwater. Geology 32: $953-$ 956.

KUMAR S, K TAMURA \& M NEI (2004) MEGA3: integrated software for molecular evolutionary genetics analysis and sequence alignment. Briefings in Bioinformatics 5: 150-163.
LIU WT, CL HUAN, JY HU, L SONG, SL ONG \& WJ NG (2002) Denaturing gradient gel electrophoresis polymorfism for rapid 16S rDNA clone screening and microbial diversity study. Journal of Bioscience and Bioengineering 93: 101-103.

LOVLEY D, HE DAUM \& KP NEVIN (2004) Dissimilatory Fe(III) and Mn(IV)

MIRANDA CD \& G CASTILLO (1998) Resistance to antibiotic and heavy metals to Chilean fresh water. The Science of the Total Environment 224: 167176.

MONTECINO V \& S CABRERA (1982) Phytoplankton activity and standing crop in an impoundment of Central Chile. Journal of Plankton Research 4: 943 950

MUYZER G, EC DE WALL \& AG UITTERLINDEN (1993) Profiling of complex microbial populations by denaturing gradien gel electrophoresis analysis of polymerase chain reaction-amplified genes coding for 16S rDNA. Applied and Enviromental Microbiology 59: 695-700.

NORICI A, R HELL \& M GIORDANO (2005) Sulfur and primary production in aquatic environments: an ecological perspective. Photosynthesis Research 86: 409-417.

PIZARRO J, MA RUBIO \& X CASTILLO (2003) Study of chemical speciation in sediments: An approach to vertical metals distribution in Rapel reservoir (Chile). Journal of the Chilean Chemical Society 48: 45-50.

REYNOLDS C; V MONTECINO; ME GRAF \& S CABRERA (1985) Short-term dynamics of a Melosira population in the plankton of an impoundment in central Chile. Journal of Plankton Research 8: 715-740.

RITTLE KA \& P COLBERG (1995) Precipitation of arsenic during bacterial sulfate reduction. Geomicrobiology Journal 13: 1-11.

RYDING SO \& W RAST (1992) The control of eutrophication of lakes and reservoirs. UNESCO, Paris, France. 375 pp.

SCHINK B \& MW FRIEDRICH (2000) Phosphite oxidation by sulphate reduction. Nature 406: 37

SCHINK B, V THIEMANN, H LAUE \& MW FRIEDRICH (2002) Desulfotignum phosphitoxidans sp. nov., a new marine sulfate reducer that oxidizes phosphite to phosphate. Archives for Microbiology 177: 381-391.

SIEGEL DE EA (1999) Microscopía óptica y caracterización de minerales. Departamento Ingeniería en Minas, Facultad de Ciencias Físicas y Matemáticas, Universidad de Chile, Santiago, Chile. 98 pp.

SIMBERLOFF DS (1972) Properties of the rarefaction diversity measurement. American Naturalist 106: 414-418.

SOTO D (2002) Oligotrophic patterns in southern Chilean lakes: the relevance of nutrients and mixing depth. Revista Chilena de Historia Natural 75: 377-393.

SPRING S, R SCHULZE, J OVERMANN \& KH SCHLEIFER (2000) Identification and characterization of ecologically significant prokaryotes in the sediment of freshwater lakes. FEMS Microbiology Reviews 24: 573-590

THOMPSON JD, TJ GIBSON, F PLEWNIAK, F JEANMOUGIN \& DG HIGGINS (1997) The CLUSTAL_X windows interface: flexible strategies for multiple sequence alignment aided by quality analysis tools. Nucleic Acids Research 25: 48764882 . 
VAN DER GUCHT K, T VANDEKERCKHOVE, N VLOEMANS, S COUSIN, K MUYLAERT, K SABBE, $M$ GILLIS, S DECLERK, L DE MEESTER \& W VYVERMAN (2005) Characterization of bacterial communities in four freshwater lakes differing in nutrient load and food web structure. FEMS Microbiology Ecology 53: 205-220.

VILA I \& R PARDO (2003) Perturbaciones antrópicas de un embalse templado. Limnetica 22: 93-102.

VILA I, M CONTRERAS, V MONTECINO, J PIZARRO \& D ADAMS (2000) Rapel: A 30 years temperate reservoir. Eutrophication or contamination? Arkiv für Hydrobiologie Special Issues Advances in Limnologie 55: 31-44.

VILA I, M CONTRERAS \& J PIZARRO (1997)
Eutrophication and phytoplankton selective responses in a temperate reservoir. Verhandlungen der Internationalen Vereiningung für Theoretische und Angewandte Limnologie 26: 798-802.

VILA I, I BARENDS \& V MONTECINO (1987) Composición, abundancia y distribución espacial y temporal del fitoplancton del embalse Rapel (1976-1977). Revista Chilena de Historia Natural 60: 37-55.

WOBUS A, C BLEUL, S MAASSEN, C SCHEERER C, M SCHUPPLER, E JACOBS \& J RÖSKE (2003) Microbial diversity and functional characterization of sediments from reservoirs of different trophic state. FEMS Microbial Ecology 46: 331-347.

ZAR J (1996) Biostatical analysis. Third edition, Prentice Hall, Upper Saddle River, New Jersey, USA. 660 p.

Associate Editor: Bernardo González

Received May 04, 2006; accepted November 13, 2006 